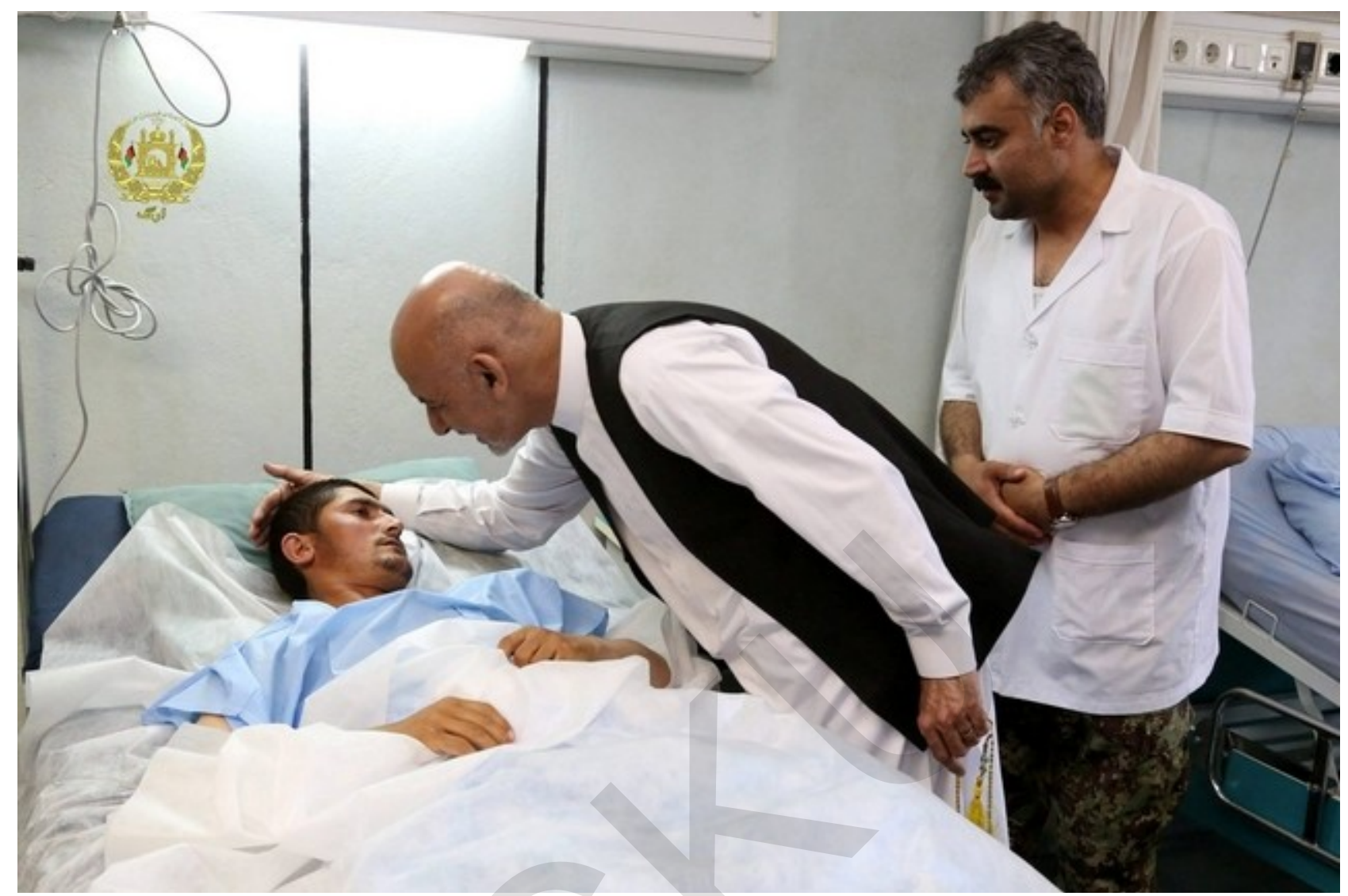

Afghanistan's President Ashraf Ghani talks with a victim wounded in April 21's attack on an army headquarters during his visit in Mazar-i-Sharif. Presidential Palace /Handout via REUTERS.

\title{
Wounded Afghan soldiers describe Taliban mowing down all in their path
}

April 23, 2017 Updated: April 23, 2017 01:16 PM

Related 


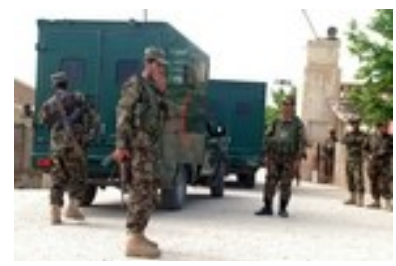

- More than 100 killed and wounded in Taliban attack on Afghanistan army base

- Top US official visits Afghanistan after megabomb attack

- $\quad$ Kandahar explosives that killed UAE ambassador to Afghanistan hidden in food

- Quetta: Symbol of Pakistan's war on militants or Taliban haven?

- $\quad$ Taliban car bomb kills 22 in north-west Pakistan

Topics:

- $\underline{\text { Afghanistan }}$

\section{Page 2 of 2}

A Taliban spokesman said at least four of the attackers were longtime members of the army who worked with the insurgent group.

Afghan officials are investigating that claim, but Zabihullah said he had no doubt that the gunmen had inside help.

"Security is so tight that even soldiers without IDs are not allowed to get in," he said.

The Afghan defence ministry said the death toll was more than 100 but expected it to change and that an investigation was under way.

Afghan president Ashraf Ghani flew to Mazar-i-Sharif on Saturday to pay a "courtesy visit" to wounded soldiers, his office said, while Gen John Nicholson, the top US commander in Afghanistan, praised Afghan commandos for bringing the "atrocity to an end".

Security forces, beset by killings and desertions, have been struggling to beat back insurgents since US-led Nato troops ended their combat mission in December 2014.

According to a US watchdog, casualties among Afghan security forces soared by 35 per cent last year, with 6,800 soldiers and police killed.

Early last month, gunmen disguised as doctors stormed the country's largest military hospital in Kabul, killing dozens.

That attack came a week after 16 people were killed in simultaneous Taliban suicide assaults on two security compounds in the capital. 
Retired Afghan Gen Atiqullah Amerkhel said the raid on Friday would further erode trust between Afghan soldiers and damage morale.

"Now they don’t know that my fellow soldier is friend or enemy, Gen Amerkhel said. "They can't trust anyone inside the Corps or outside.

"When they hear or see that this many troops were massacred, then how can they think they will succeed on the battleground?"

* With reporting from Fazelminallah Qazizai in Kabul, Reuters and Agence France-Presse 